\title{
球状黒鉛鋳鉄埋設管の黒鉛化腐食における バクテリアの役割
}

\author{
笠原晃明*, 梶山文夫*, 岡 村 潔* \\ * 東京ガス株式会社 基礎技術研究所
}

\begin{abstract}
The Role of Bacteria in the Graphitic Corrosion of Buried Ductile Cast Iron Pipes
\end{abstract}

\author{
Komei Kasahara*, Fumio Kajiyama* and Kiyoshi Okamura* \\ * Fundamental Technology Research Laboratory, Tokyo Gas Co., Lta.
}

\begin{abstract}
Localized corrosion on buried ductile cast iron pipes was investigated placing the main emphasis on the morphology of corrosion attack and the action of microorganisms. The form of corrosion was classed as selective leaching attack commonly referred to as graphitic corrosion. It was found that each nodular graphite was supported by amorphous silica and iron carbonate, thereby constituting a porous graphite mass that is characteristic of graphitic corrosion. Microbial enumeration and electrochemical observations strongly suggested a possibility that a symbiotic proliferation of iron bacteria and iron oxidizing bacteria was primarily responsible for accelerated localized selective leaching as well as tubercle formation. Results of EPMA analysis indicated that amorphous silica was formed as a result of metabolism of such bacteria to form both porous graphite mass and tubercles.
\end{abstract}

Key words: buried ductile cast iron, graphitic corrosion, microbially influenced corrosion, tuberculation, amorphous silica

\section{1. 緒言}

黒鉛化腐食は，「金属成分が選択的に腐食・溶出し， 黒鉛が元の位置に多孔性の脆い集合体を形成して残され る, ねずみ鋳鉄特有の劣化形態」で,「黒鉛がネットワー クを形成していない球状黒鉛鋳鉄，可鍛鋳鉄では，黒鉛 残椬の保持機能を欠くため見られない」とされている1)。 しかし，球状黒鉛鋳鉄埋設管では，ねずみ鋳鉄埋設管 の黒鉛化腐食と全く同様に，土やさびを落とした時に一 見健全そらに見える所でも，テスト・ハンマーでたたく と本来の強度が失われているため, 初めて腐食していた ことに気付くといらことが，しばしば経験されている。 今回, 腐食性がごく低い土畩中に埋設されていた球状 黒鉛鋳鉄管が， $0.3 \mathrm{~mm} / \mathrm{y}$ といらような急速な局部腐食 を被った原因を調べていたところ, 球状黒鉛鋳鉄でも黒 鉛化腐食が起こり，その過程でバクテリアが深くかかわ っていたと考えるに足る興味ある結果が得られたので， 以下に報告する。

* 東京都港区芝浦 1-16-25 (1-16-25, Shibaura， Tokyo, 105 Japan)

\section{2. 試 験 方 法}

\section{1 現 場 試 験}

埋設後 14 年経過した呼び径 $200 \mathrm{~mm}$, 肉厚 $10 \mathrm{~mm}$ の 球状黒鉛鋳鉄管の掘削腐食調査を行ったところ，大きな さび瘤を伴った浅いボウル状をした局部腐食が，最大 $0.3 \mathrm{~mm} / \mathrm{y}$ の速度で起こっている場所が見つかった。そ こで大量の瞬間接着剂を施して管の一部をさび瘤付きの まま掘り上げ, EPMA で観察した。また, ボウル状の局 部腐食孔から採取された腐食生成物, 付近の土壤の分析 も行った。

\section{2 実験室試験}

腐食性がごく低いと考觉られていた土壤中で急速な局 部腐食がもたらされた原因を明らかにするため，現場か ら採取された土壌を実験室に持ら帰り, 電気化学的モ二 タリングを行いつつ埋設腐食試験を行った。

Fig. 1 は試験に用いたプローブの外観で, 板厚 $8 \mathrm{~mm}$, 面積 $6 \mathrm{~cm}^{2}(30 \mathrm{~mm} \times 20 \mathrm{~mm})$ の球状黒鉛鋳鉄片を試料 極, これと $15 \mathrm{~mm}$ の距離を隔てて平行に設置された 同面積の白金板を対極，試料極特よび対極の端から 10 


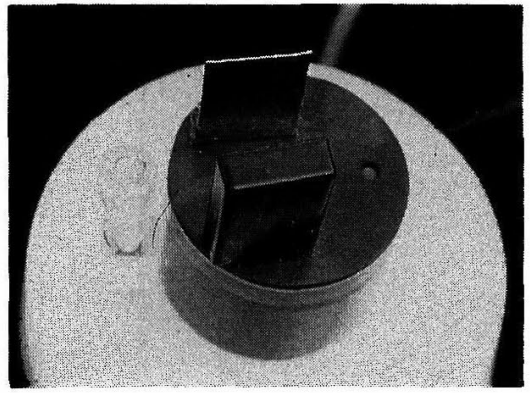

Fig. 1 Triangular spaced type 3-electrode probe used in the burial corrosion testing in the laboratory.

$\mathrm{mm}$ の 3 角形の頂点の位置に設置した $\mathrm{Ag} / \mathrm{AgCl}$ 電極を 照合極と寸る 3 電極型プローブである。なお，試料極の 表面は 1500 番のエメリ一紙で研磨した後アセトンで脱 脂乙, 対極と相対与る面を残して耐水性絶縁塗料学塗布 した。

このプローブを, 内容積 $1 l$ のパイレックス・ガラス 製容器に充填した土壤中に埋設して腐食セルを作成し, $30^{\circ} \mathrm{C}$ のインキュベータに入れて 90 日間自然腐食させ た。その間一定時間ごとに腐食電位と ACインピーダン スを測定した。秃た,試験の開始時むよび終了時の 2 回, 分極测定を行った。腐食せルは複数個用意し, 内 2 つは 30 日目の時点で取り出して, 重量減測定捻よび EPMA 観察に供した。な执, 測定された電位は, 文献 ${ }^{2)}$ に記載 されている值を用いて，土㙵腐食で一般的な $\mathrm{Cu} / \mathrm{CuSO}_{4}$ （飽和）電極基準に換算し，本文中で使用した。

$\mathrm{AC}$ インピーダンス測定は, ポテンショスタットと周 波数特性解析器とを組又合わせて, $10 \mathrm{mV} \mathrm{rms}$ の正弦波 電圧を $10 \mathrm{kHz}$ から $1 \mathrm{mHz}$ まで掃引させる方法で行っ た。

分極測定は, 液抵抗補正を施しつつ, 腐食電位から 2 $\mathrm{mV}$ きざみで電压を增加させるごとに極性を切り替えて 10 秒間印加するという力法で，腐食電位士 $500 \mathrm{mV}$ まで の範囲で行った。

埋設環境の变化を見るため, 試験の前後に土䁃の分析 および鉄細菌（IB），鉄酸化細菌 (IOB)，硫酸塩還元菌 (SRB), メタン生成菌 (MPB), 硫黄酸化細菌 (SOB) など のバクテリアの計数を行った。土壤の分析は, 土壤微生 物研究会推奖基準 ${ }^{3)}$ に準拠して行った。硫酸塩還元囷の 計数は, Postgate の B 培地地を用いて行った。その他 のバクテリアの計数は, 文献 ${ }^{3)}$ に記載されている推奨法 に準拠して行った。

\section{3. 試験結果および考察}

\section{1 現場試験}

Fig. 2 は,さび瘤付さのま掘り上げられた球状黑鉛

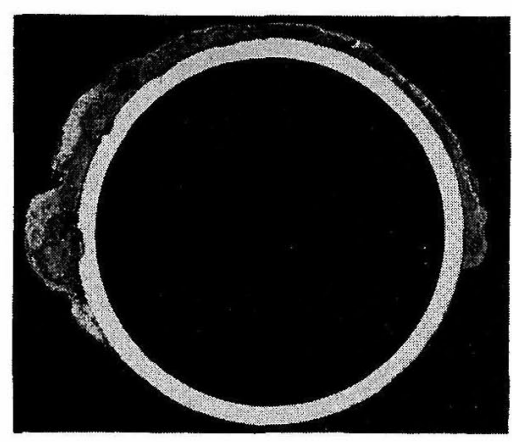

Fig. 2 Cross section of a 200-mm diam ductile cast iron pipe buried for 14 years.

䤣鉄管の断面で，上下関係は現場のままである。管の上 側の方が土壤との密着性が良いため，笍食は管の上半分 に限定されて扣り，浅いボウル状に侵食された局部腐食 孔を，大さなさび溜が覆い䧟す形で腐食が起こってい る。さび瘤の体積は，腐食された球状黑鉛鋳鉄の体積の 数十倍ない乙は数百倍に及几で拈り，全体的に工業用水 中のステンレス鋼のバクテリア腐食で見られた様相に酷 似している5)。

Fig. 3 は, Fig. 2 の時計の 9 時に相当する部分を EPMAで観察した結果である。球状黒鉛鋳鉄から Fe が 選択的に溶出して大きなさび瘤を形成しているが，管の 原形はそのまま保たれているのが特徴である。さび瘤に はごく微小な土粒子が巻き込李れてはいるbのの，大半 は Fe および Si の化合物で棈成されており, 特にさび 瘤の外殼はほとんぞ Si の化合物で占められている。一 方, ボウル状をした局部腐食孔の中には, S と Si の濃縮 が見られるほか，全体としてさび瘤とは異なった成分か ら構成されているよらに見光る。最大腐食深さは 3.5 $\mathrm{mm}$ あり，腐食速度にすると $0.25 \mathrm{~mm} / \mathrm{y}$ になるが，これ は関東地方の土堙中に扣ける自然腐食速度としてはトッ プクラスにランクされる゙゚。

Fig. 4 は, Fig. 3 の腐食孔の一部を高倍率で観察した

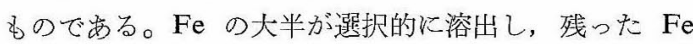
と，代わりに浸入した $\mathrm{Si}$ とが球状黒鉛を元の位置で支 えて, 多孔性の腐食残渣を形成している。 $\mathrm{Si}$ は, 薄いつ レーク状の化合物として存在して扣り，量的には，局部 腐食孔の底よりも, 出口側の方が多い。また， $\mathrm{S}$ は，Fe

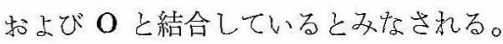

Fig. 5 は, 局部腐食孔内の残椬の X 線回折パターン で岁る。腐食残渣は，炭酸鉄，黒鉛，および，非晶質の シリカないしはシリケートから構成されて和り，Fe の 選択的溶出で牫された球状黑敛を，炭酸鉄と非晶質シリ カとが元の位置で支えることによって管の原形が維持さ れて和り，腐食形態としては，いわゆる「黒鉛化腐食」 


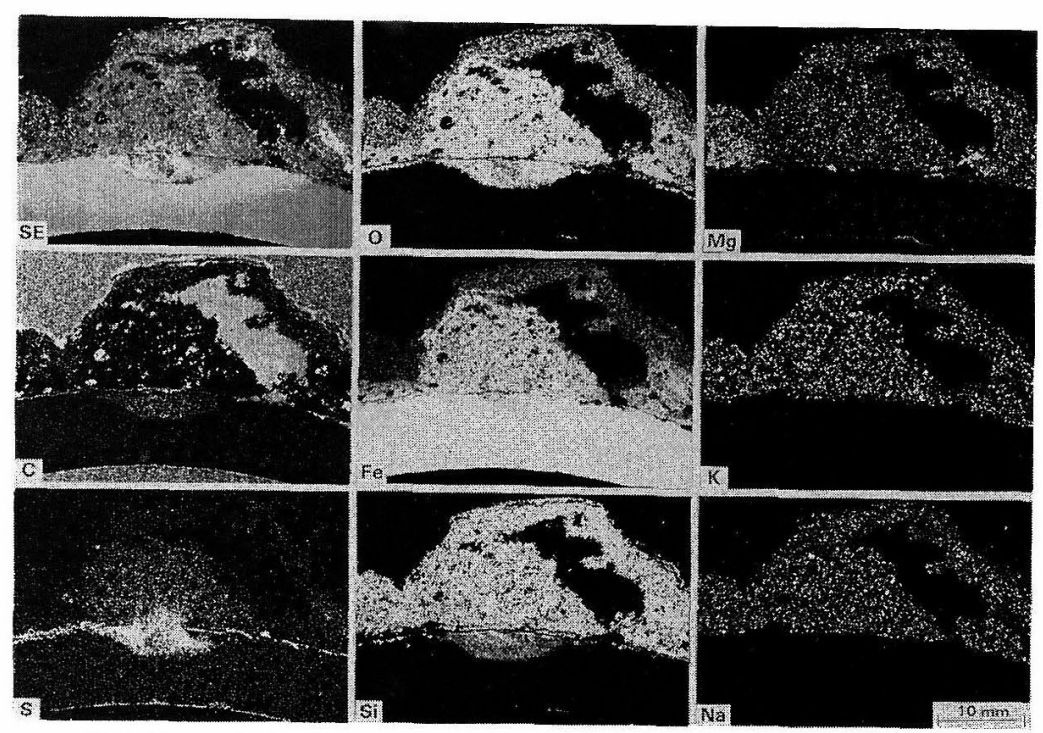

Fig. 3 EPMA analysis of the cross section in Fig. 2 at the location of 9 o'clock.

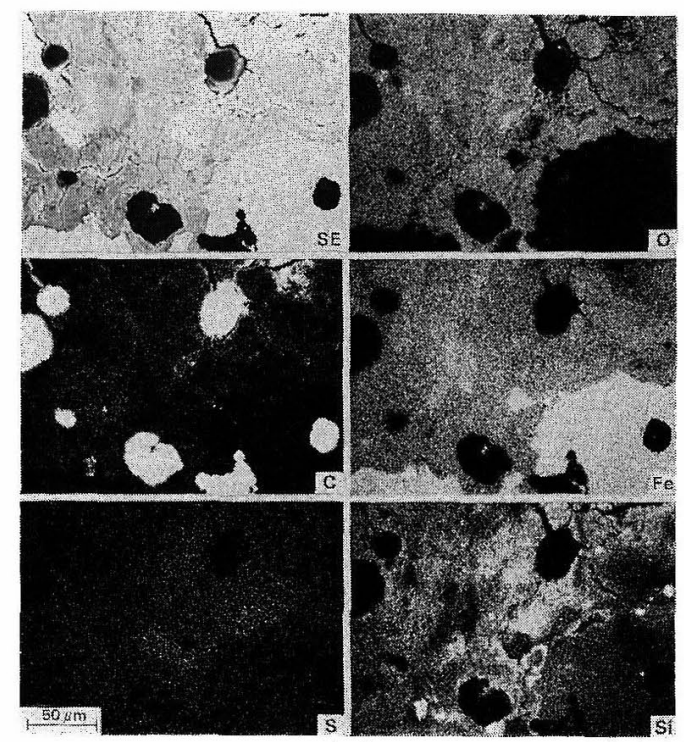

(a)

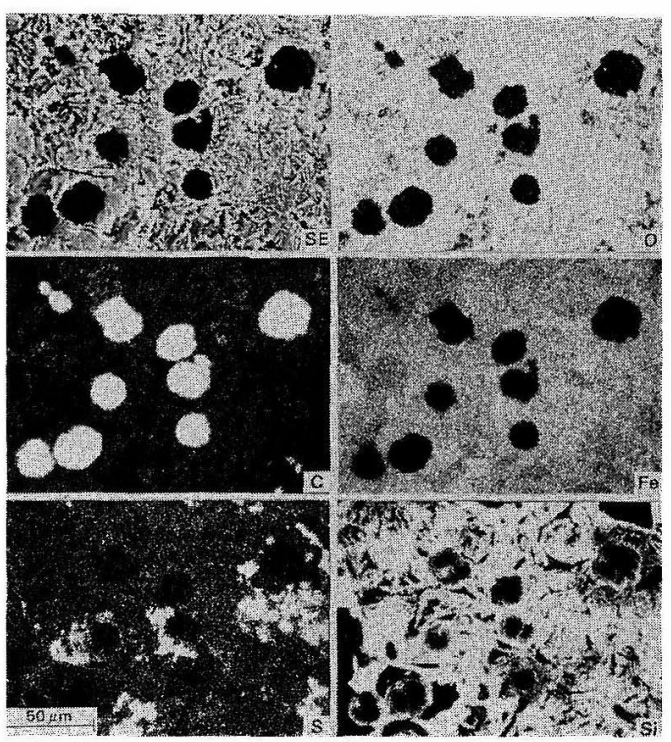

(b)

Fig. 4 EPMA analysis of the corrosion products in the pit shown in Fig. 3.

(a) bottom of the pit, (b) near the mouth of the pit

に分類されるものであることが分かる。

一方, さび瘤の X 線回折では, $\gamma-\mathrm{FeOOH}, \mathrm{Fe}_{3} \mathrm{O}_{4}, \alpha$ $\mathrm{SiO}_{2}$ (Quartz)，および Fig. 5 と同じ非晶質シリカ（ま たはシリケート）が同定された。

Table 1 は, 管のごく近傍の土堆の分析結果である。 DVGW のワークシートGW97) に準拠して腐食性を評 洒すると総合点は 0 となり，「通常ではほとえど腐食の 心配はない土壤」Kランクされる。ちなみに, 総合点が
0 以上：腐食性なL， $0 \sim-4$ ：わずかに腐食性， -4 -10：かなり腐食性, -10 以下：激しい腐食性である。 また, 現場に括子る管対地電位, 地対地電位を測定し た結果, マクロセルや迷走電流といった特別な腐食の駆 動力が存在していた形跡は認められなかった。

\section{2 実験空試験}

腐食性がごく低い土壌中で, マクロセルや迷走電流と いった特別な駆動力も作用していないにもかかわらず, 
Sample: GRACR1 File: [300,5]GPACR1.SH 29-JAl1-91 15:17

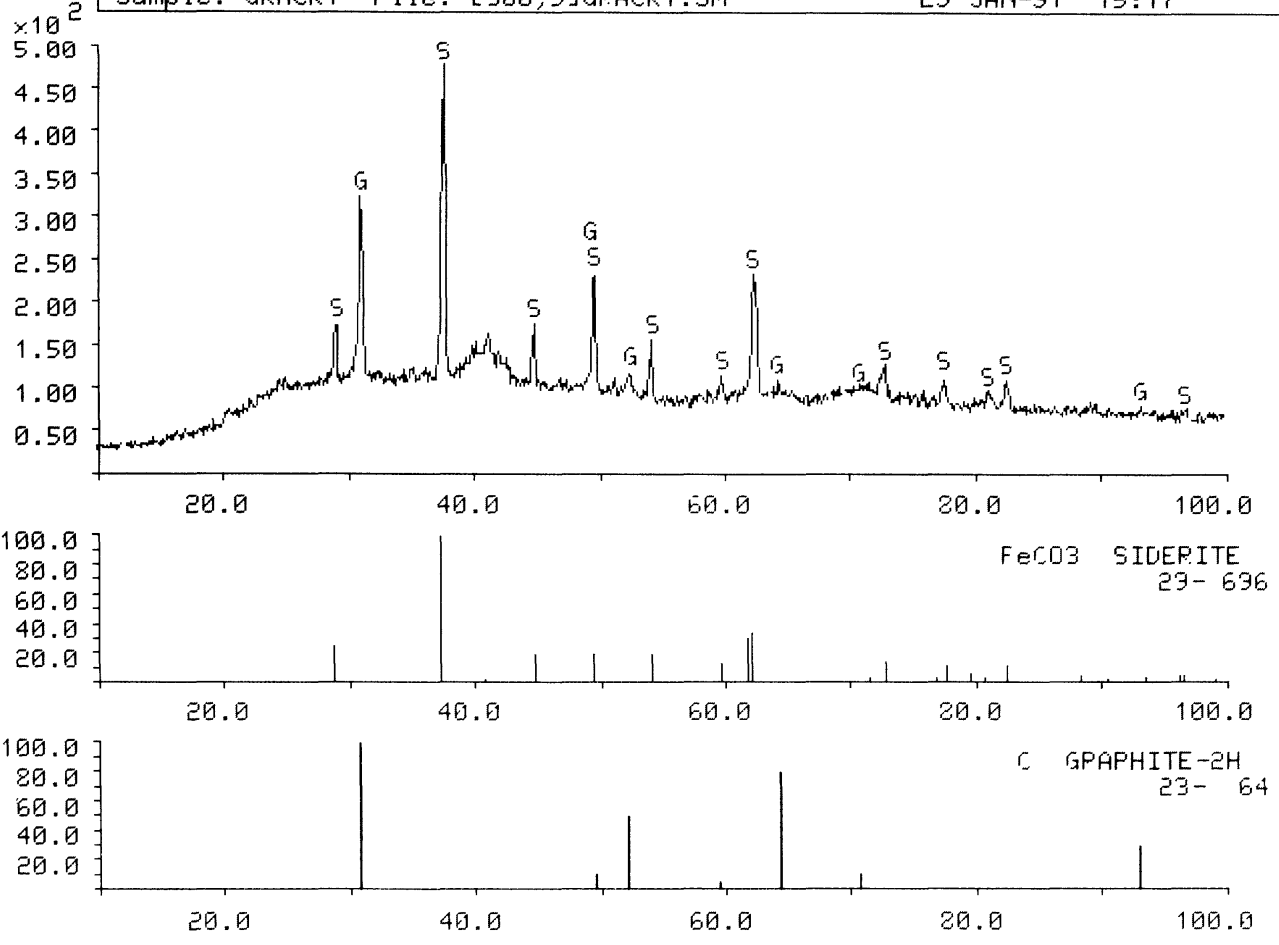

Fig. 5 X-ray diffraction pattern of the corrosion products in the pit.

Table 1 Properties of the soil at the immediate vicinity of the localized corrosion area shown in Fig. 1.

\begin{tabular}{llc}
\hline \multicolumn{1}{c}{ Factor } & Measurement & GW 9 index $^{6)}$ \\
\hline Type & Sand & +2 \\
Condition & Natural, Similar & 0 \\
Resistivity & $5230 \Omega \cdot \mathrm{cm}$ & -1 \\
Water content & $24.5 \%$ & -1 \\
$\mathrm{pH}$ & 8.25 & 0 \\
Redox & $399 \mathrm{mV}$ vs. NHE & 0 \\
Coal & nil & 0 \\
$\mathrm{Cl}^{-}$ & $18 \mathrm{mg} / \mathrm{kg}$ & 0 \\
$\mathrm{SO}_{4}^{2-}$ & $116 \mathrm{mg} / \mathrm{kg}$ & 0 \\
\hline Total & & 0 \\
\hline
\end{tabular}

$0.3 \mathrm{~mm} / \mathrm{y}$ といらような急速な局部腐食が起こった原因 を明らかにするため, 現場の土壤を実験室に持ち帰り, 電気化学的モニタリング手法を併用して, 埋設腐食試験 を行った。

Fig. 6 および Fig. 7 は, 試験開始後 30 日目に掘り 上げたプローブの試料極断面を EPMA で観察した結果 である。試料極表面に一部露出していたとみられる球
状黒鉛/鉄境界から局部腐食が始まっており，その上に， microbially influenced corrosion の特徵之される火山 の噴火を思わせる形のさび瘤8) が生長し始めている。さ び瘤は主として Fe と Si とから成っていて, Fig. 3 で 見られたのと同様に，ごく小さな土粒子は巻き込むもの の, 大きな砂利は押しのける形で生長して抒り, その体 積は腐食溶出部の数十倍はある。Fe が溶出した後に $\mathrm{S}$ と $\mathrm{Si}$ が浸入して腐食孔の中に腐食残椬を形成していく 様子も，現場で見られたものとまったく同じである。ま た, 最大腐食深さは $0.12 \mathrm{~mm}$ に達して和り,このまま進 むと, 現場の 5 倍の $1.5 \mathrm{~mm} / \mathrm{y}$ 近い速度の局部腐食がも たらされることになるが， $30^{\circ} \mathrm{C}$ といら試験温度を考光 ると，ほぼ妥当なレベルである。

このように現場で見られた腐食現象は, 形態的にも， また速度的にも，完全に実験室で再現されている。

Table 2 は, 90 日にわたる埋設試験の前後の埋設環境 の変化をみたものである。試料極表面から約 $1 \mathrm{~mm}$ まで の範囲に和汗る鉄細菌, 鉄酸化細菌, 硫黄酸化細菌の計 数值と $\mathrm{Fe}^{2+}$ 量が著しく増加しているが, 硫酸塩還元菌, メタン生成菌, $\mathrm{FeS}$ はむしろ減少している。な括, 鉄細 菌は, 多数が集まって紐状を成して生育していて計数 がむずかしいため, +〜+十+の3 段階表示にしてめ る。

これらのバクテリアの腐食への奇与についてはまだ定 


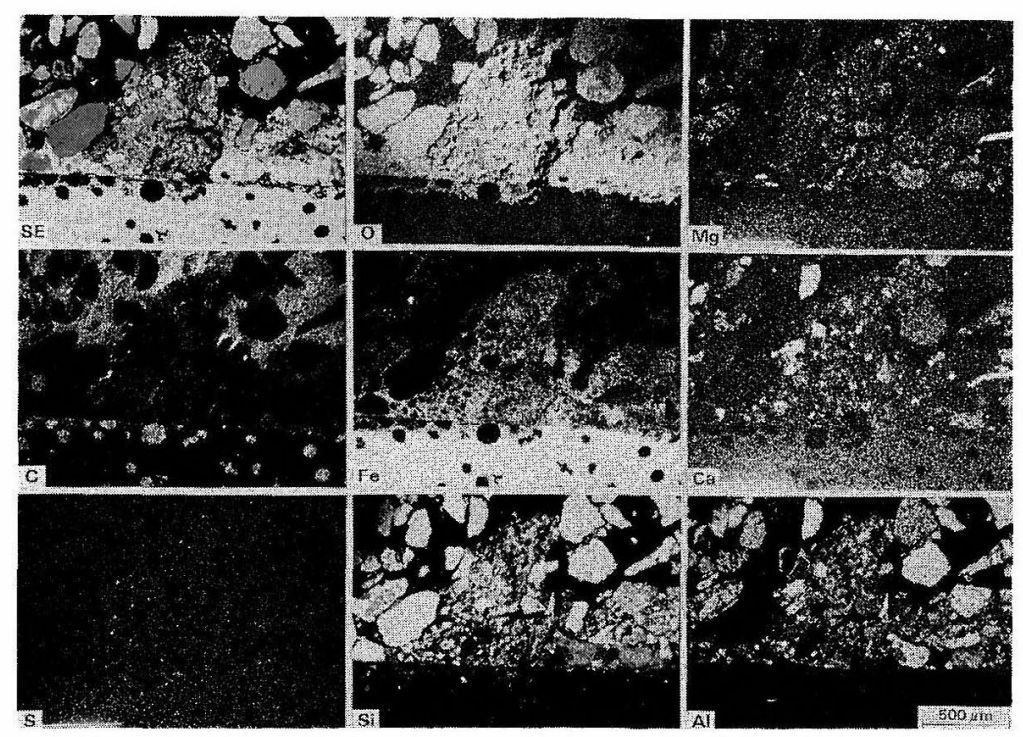

Fig. 6 EPMA analysis of the cross section through a localized corrosion area on a ductile cast iron coupon buried for 30 days.

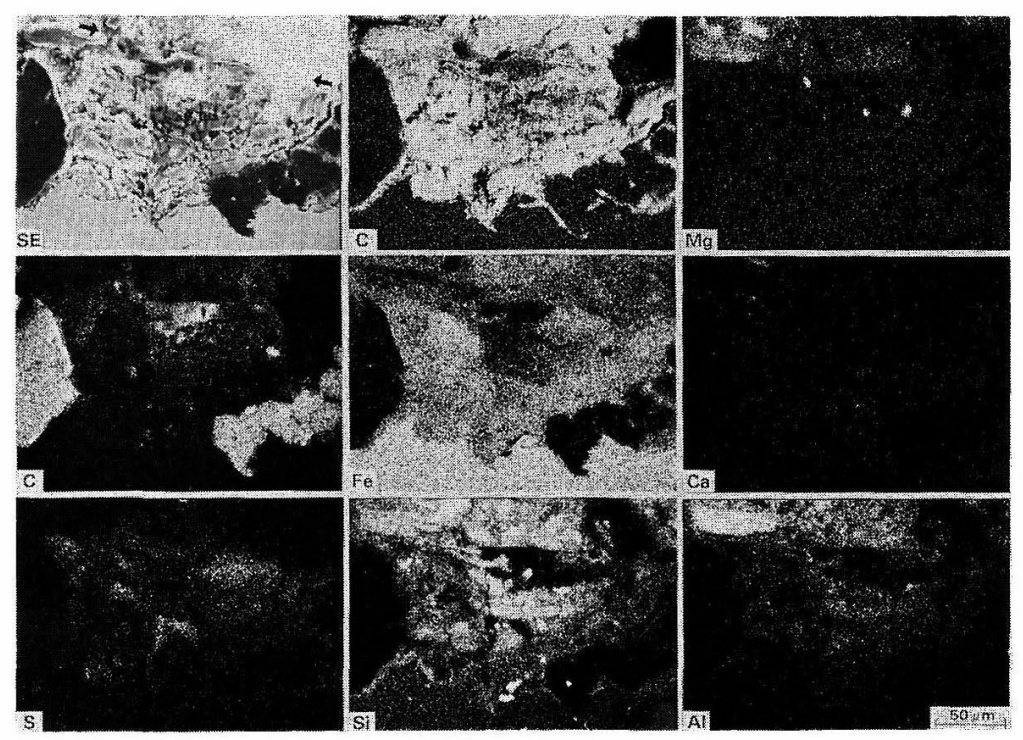

Fig. 7 Close-up of the cross section in Fig. 6. Arrows indicate the position of original surface.

Table 2 Change in burial environment observed in the laboratory burial testing.

\begin{tabular}{|c|c|c|c|c|c|c|c|c|c|c|c|c|c|c|c|c|}
\hline \multirow{2}{*}{$\begin{array}{l}\text { Time } \\
\text { (day) }\end{array}$} & \multirow{2}{*}{ Location } & \multirow{2}{*}{$\begin{array}{c}\text { Eh } \\
\text { (ImV NHE) }\end{array}$} & \multirow{2}{*}{$\mathrm{pH}$} & \multicolumn{8}{|c|}{ Chemical species (wt-ppm) } & \multicolumn{5}{|c|}{ Bacteria (cell/g-soil) } \\
\hline & & & & $\mathrm{Fe}^{2+}$ & Fe S & $\begin{array}{c}\text { Formic } \\
\text { acid }\end{array}$ & $\begin{array}{c}\text { Succinic } \\
\text { acid }\end{array}$ & $\mathrm{HCO}_{3}^{-}$ & $\mathrm{SO}_{4}^{2-}$ & $\mathrm{Cl}^{-}$ & $\mathrm{NO}_{3}^{-}$ & ІОВ & SOB & IB & SRB & MPB \\
\hline 0 & Bulk & 399 & 8.25 & 19 & 75 & ND & 1 & 326 & 116 & 18 & 1 & $2 \times 10$ & 0 & ++ & $8 \times 10$ & $2 \times 10^{2}$ \\
\hline \multirow{2}{*}{90} & Bulk & 374 & 7.23 & 83 & 20 & ND & 3 & 200 & - & - & - & $8 \times 10$ & $2 \times 10$ & ++ & $4 \times 10$ & $1 \times 10^{2}$ \\
\hline & $\begin{array}{c}\text { Electrode/soil } \\
\text { interface }\end{array}$ & 399 & 5.61 & 147 & 27 & 1 & ND & 271 & - & - & - & $3 \times 10^{4}$ & $9 \times 10$ & +++ & $3 \times 10$ & $4 \times 10$ \\
\hline
\end{tabular}


Table 3 Action of bacteria implicated in the soil corrosion.

\begin{tabular}{ccccl}
\hline \multicolumn{1}{c}{ Species } & $\begin{array}{c}\text { Oxygen } \\
\text { requirement }\end{array}$ & $\begin{array}{c}\mathrm{pH} \\
\text { range }\end{array}$ & $\begin{array}{c}\text { Temperature } \\
\left.\text { range ( }{ }^{\circ} \mathrm{C}\right)\end{array}$ & \multicolumn{1}{c}{ Action } \\
\hline $\begin{array}{c}\text { IB } \\
\text { Gallionella }\end{array}$ & Aerobic & $7.5 \sim 9.5$ & $20 \sim 30$ & $\begin{array}{l}\text { Oxidize } \mathrm{Fe}^{++} \text {to } \mathrm{Fe}^{+++} \\
\text {Promote tuberculation }\end{array}$ \\
$\begin{array}{c}\text { IOB } \\
\text { Thiobacillus } \\
\text { ferrooxidans }\end{array}$ & Aerobic & $0.5 \sim 6.0$ & $10 \sim 40$ & $\begin{array}{l}\text { Oxidize } \mathrm{Fe}^{++} \text {to } \mathrm{Fe}^{+++} \text {in } \\
\mathrm{H}_{2} \mathrm{SO}_{4} \text { and } \mathrm{HCl}_{\text {environments }}\end{array}$ \\
$\begin{array}{c}\text { SOB } \\
\text { Thiobacillus } \\
\text { thiooxidans }\end{array}$ & Aerobic & $0.5 \sim 6.0$ & $10 \sim 40$ & $\begin{array}{l}\text { Oxidize } \mathrm{S} \text { and sulfides to } \\
\text { form } \mathrm{H}_{2} \mathrm{SO}_{4}\end{array}$ \\
$\begin{array}{c}\text { SRB } \\
\text { Desulfovibrio }\end{array}$ & Anaerobic & $5.5 \sim 7.5$ & $25 \sim 45$ & $\begin{array}{l}\text { Promote cathodic reactions } \\
\text { and formation of sulfides }\end{array}$ \\
MPB & Anaerobic & $4 \sim 8$ & $25 \sim 45$ & $\begin{array}{l}\text { Consume acetic acid to } \\
\text { form methane }\end{array}$ \\
\hline
\end{tabular}

説はないが，およそ Table 3 であろらとされている。今 の場合, 試料極表面の $\mathrm{pH}$ が試験前の 8.25 から 5.61 へ と低下した反面, $\mathrm{HCO}_{3}{ }^{-}$は試験期間を通じて高レベル に維持され，通常の腐食では見られないかさ高なさび瘤 が生成している。従って, 酸性環境を好む鉄酸化細菌と 硫黄酸化細菌の働きで $\mathrm{H}_{2} \mathrm{SO}_{4}$ ないしは $\mathrm{FeSO}_{4}$ が形成さ れ，腐食孔内が硫酸酸性飞維持されて，Fe の溶解が進 む一方，中性環境を好む鉄細菌の影響下で $\mathrm{FeCO}_{3}$ と $\mathrm{FeOOH}$ が形成され，腐食孔からさび瘤の外殼を埋めて いたと考觉ると, EPMA 観察, X 線回折の結果が, よく 説明される。

数十 $\mathrm{ppm}$ の $\mathrm{HCO}_{3}$-を含む環境下に护ける $\mathrm{Fe}$ の腐 食は, 次の (1) から (4) のよらな経路で起こるとされて (る⿱日)

$$
\begin{aligned}
& \mathrm{Fe}+2 \mathrm{H}_{2} \mathrm{O} \rightarrow \mathrm{Fe}(\mathrm{OH})_{2}+2 \mathrm{H}^{+}+2 \mathrm{e}^{-} \\
& \mathrm{Fe}(\mathrm{OH})_{2}+\mathrm{HCO}_{3}{ }^{-} \rightarrow \mathrm{FeCO}_{3}+\mathrm{H}_{2} \mathrm{O}+\mathrm{OH}^{-} \\
& \mathrm{FeCO}{ }_{3}+\mathrm{HCO}_{3}{ }^{-} \rightarrow \mathrm{Fe}\left(\mathrm{CO}_{3}\right)_{2}{ }^{2-}+\mathrm{H}^{+} \\
& \mathrm{Fe}\left(\mathrm{CO}_{3}\right)_{2}{ }^{2-}+1 / 4 \mathrm{O}_{2}+3 / 2 \mathrm{H}_{2} \mathrm{O} \rightarrow \\
& \mathrm{FeOOH}+2 \mathrm{HCO}_{3}{ }^{-}
\end{aligned}
$$

この反応機構は, 今の球状黒鉛鋳鉄の局部腐食によく あてはまる。すなわち, 球状黒鉛と素地との間のガルバ ニックセルを駆動力とする (1) の反応が，腐食孔内に棲 みついた鉄酸化細菌, 硫黄酸化細菌の代謝の結果作り出 された $\mathrm{H}_{2} \mathrm{SO}_{4}$ ないしは $\mathrm{FeSO}_{4}$ の低 $\mathrm{pH}$ 環境下で促進 されるとともに，その環境はこれらの耐酸性菌にとって ますます快適なものとなる。この腐食反応の初期生成物 である $\mathrm{Fe}(\mathrm{OH})_{2}$ の保護性皮膜は, 土壤から供給された $\mathrm{HCO}_{3}{ }^{-}$によって (2) のように溶解され, $\mathrm{FeCO}_{3}$ が腐食 孔内を埋める。そこへさらに $\mathrm{HCO}_{3}$ - が供給されると， 腐食孔内を埋めていた $\mathrm{FeCO}_{3}$ は (3) の反応により再び 溶解し，腐食孔の外一と運ばれる。そこに中性環境を好 む鉄細菌が生息し，乙かもその活性が高いと，引き続き

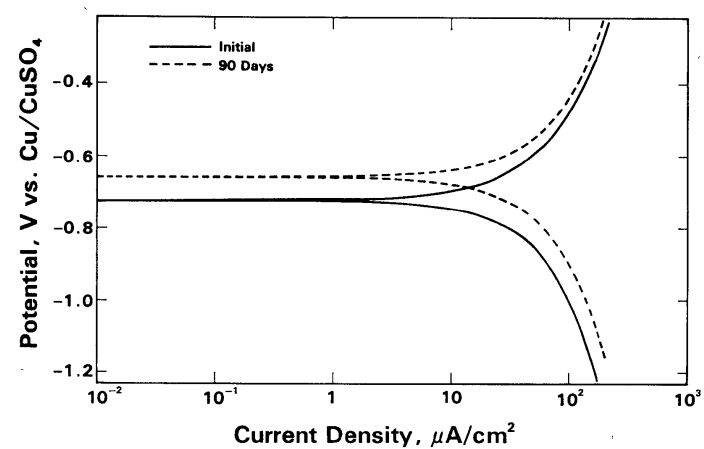

Fig. 8 Polarization curves obtained in the laboratory burial testing.

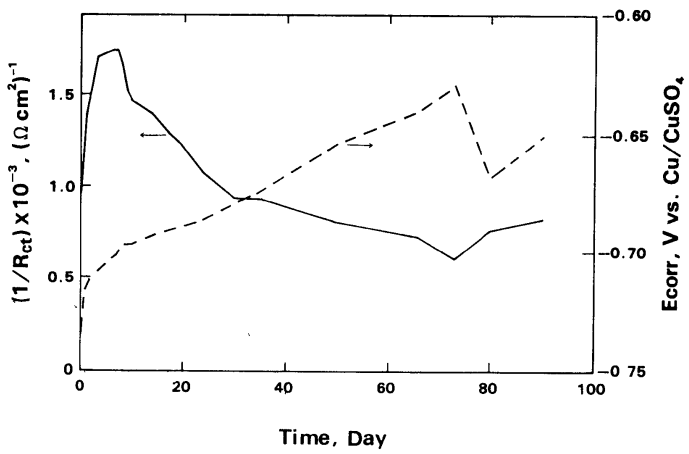

Fig. 9 Change with time of corrosion potential $\left(E_{\text {corr }}\right)$ and charge transfer resistance $\left(R_{\mathrm{ct}}\right)$ observed in the laboratory burial testing.

(4) の反応によって $\mathrm{Fe}^{2+}$ が $\mathrm{Fe}^{3+}$ に変えられ, 生成した $\mathrm{FeOOH}$ はさび瘤の生成に使われ酸素濃淡電池の駆動力 を増大させる。その結果 $\mathrm{HCO}_{3}$ - は再び (2) または (3) の反応使用される。こうして環境中の $\mathrm{HCO}_{3}{ }^{-}$快高レ ベルに維持され，際限なく腐食が継続すると考兄られる る。 


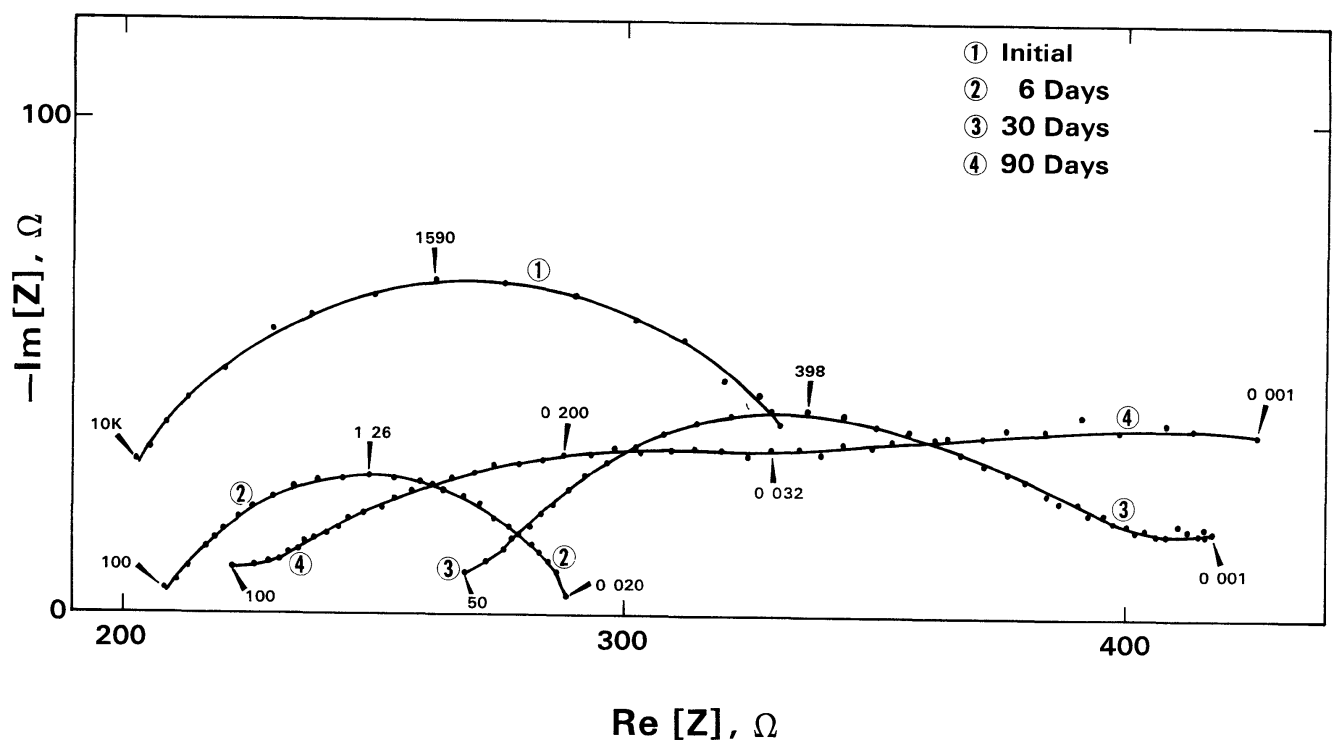

Fig. 10 Change with time of AC-impedance spectra observed in the laboratory burial testing.

Fig. 8 は, 分極測定の結果である。腐食電位がいくぶ ん貴方向ヘシフトしていることを除けば，曲線の位置と 形は90 日間で淿とんど変化していない。これは, 本来 溶解度積が小さく，腐食反応を抑制する側にをわるはず の $\mathrm{Fe}(\mathrm{OH})_{2}$ が，上述のような $\mathrm{HCO}_{3}$ - が関与したサイ クリックな腐食反応機構によって消費され, 腐食速度が 高いレベル飞維持されていることを裏付けている。

Fig. 9 特よび Fig. 10 は, 腐食電位拉よび AC イン ピーダンス測定の結果である。Fig. 9 で縱軸を $1 / R_{\mathrm{ct}}$ で プロットしてあるのは, 腐食速度 $d(\mathrm{~mm} / \mathrm{y})$ と電荷移動 抵抗 $R_{\mathrm{ct}}\left(\Omega \cdot \mathrm{cm}^{2}\right)$ との間に,

$$
d=130.0 / R_{\mathrm{ct}}
$$

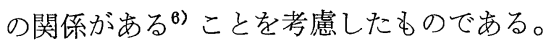

Fig. 9 亿見られるように, 腐食速度は当初非常に大き かったが，埋設開始後 7 日目くらいから次第に減少し始 め, 30 日目以降は $0.15 \mathrm{~mm} / \mathrm{y}$ 前後のレベルに落ち着い た。腐食速度が減少したとはいえ, この $0.15 \mathrm{~mm} / \mathrm{y}$ とい らレベルは, 関東地方に护ける平均土壌腐食速度 ${ }^{8)}$ より 一けた大きいものであることは注目に值する。

このような腐食速度の経時变化汶対応して, AC イン ピーダンス・スペクトルは, 埋設初期の容量性半円形か ら，埋設末期の二つの扁平化した容量性半円からなるも のへと変化したが，これは鉄酸化細菌の活性が高い場合 飞特徴的な様相である ${ }^{10)}$ 。30 日目に見られたよらな, 環 境の高比抵抗化を示唆しつつも, 腐食速度は相変わらず 高いレベルにあることを示すようなスペクトルのシフト は，鉄細菌の作用によるさび瘤生成に関係があるものと 考光られる。

今回の試験で明らかになった幾つかの事実の中で特筆
すべきは，腐食孔およびさび瘤中における $\mathrm{Si}$ の濃縮で ある。この $\mathrm{Si}$ が, 球状黒鉛鋳鉄中に含まれている $\mathrm{Si} の$ 溶解・再析出によるものではないことは，その量と分布 の仕方から明らかである。ボイラー水, 循環集中給湯水 のような温度の高い環境中でシリカのスケールが形成さ れた例はよく聞くが，常温では，著者らが工業用水中の ステンレス鋼のバクテリア腐食で形成されたさび瘤で観 察した占)以外には例がない。この時は, 鉄酸化細菌抒よ び鉄細菌が Si の濃縮に関与していた形跡が認められた が，今回の場合も同じである。

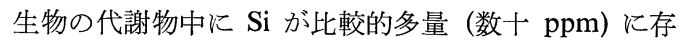
在することは知られているが11), 鉄酸化細菌, 鉄細菌の 代謝と $\mathrm{Si}$ の関係については明らかでない。XPS で局部 腐食孔内に存在する非晶質シリカの $\mathrm{Si}(2 p)$ の結合エネ ルギーをみると, $102.6 \mathrm{eV}$ であり，水晶： $102.9 \mathrm{eV，シ}$ リカゲル: $103.2 \mathrm{eV}$ ，ガラス：102.6 eV との比較から, その性状はむしろガラスに近いもので, これが局部腐食 孔の入口からさび瘤外壳に至る部分を埋めてさび瘤を補 強し, 酸素濃淡電池の駆動力を增強する形で腐食に寄与 していたことが予想される。

\section{4. 結 言}

球状黒鉛鋳鉄埋設管の局部腐食を，腐食形態，バクテ リアの作用との関連，の二つに主に視点を置いて調べ， 以下の結論を得た。

1）球状黒鉛鋳鉄埋設管の腐食は, 金属成分の選択的 溶出と大きなさび瘤生成とを伴ら局部腐食の形で起こっ たが，局部腐食孔内に残された球状黒鉛が，炭酸鉄と非 晶質シリカ（またはシリケート）とから成る多孔性残渣 
によって元の位置に支えられ，そのために腐食後も管の 原形が維持されていることから，腐食形態としては黒鉛 化腐食に分類するのが適当である。

2）従来の評価基準では“汪とんど腐食性なし”之判 定される土壤中で, マクロセルのような特別な腐食の駆 動力も存在しないにもかかわらず， $0.3 \mathrm{~mm} / \mathrm{y}$ といらよ らな急速な局部腐食が発生した原因は，

a）腐食孔内淒みついた鉄酸化細菌, 硫黄酸化細菌 の働きで生成した $\mathrm{FeSO}_{4}, \mathrm{H}_{2} \mathrm{SO}_{4}$, とよる $\mathrm{pH}$ 低 下

b) 腐食孔出口からさび瘤外殼に至るサイトで，鉄細 菌の代謝が $\mathrm{HCO}_{3}$-のリサイクルをるたらしたこ とによる $\mathrm{Fe}(\mathrm{OH})_{2} \rightarrow \mathrm{FeCO}_{3} \rightarrow \mathrm{FeOOH}$ の経路の 腐食反応の促進

c) その結果生成した $\mathrm{FeOOH}$ と, 代謝物の非晶質シ リカ（またはシリケート）とでさび瘤が補強され たことによる酸素濃淡電池の駆動力増強

といら形のバクテリアの連携プレイが演じられたことに よる。

終わりに，分析にご協力いただいた東京ガス(株)基礎 技術研究所分析テクノセンターの杉本秀夫氏, 則 徹広 氏に感謝します。

\section{文献}

1) R. Steigerwald: "Metals Handbook", 9th Ed., Vol. 13, "Corrosion", p. 133, ASM International (1987).

2） H. H. ニーリック著, 岡本 剛監修, 松田誠吾, 松島 簃共訳：「腐食反応とその制御」, p. 34, 産 業図書 (1974).

3）土壌微生物研究会編：「土袞微生物実験法」, 養賢 堂 (1981).

4) J. R. Postgate: "The Sulphate-reducing Bacteria", p. 26, Cambridge University Press (1979).

5）笠原晃明, 梶山文夫：第 36 回腐食防食討論会講 演集, p. 449 (1989).

6) K. Kasahara \& F. Kajiyama: Corrosion, 39, 475 (1983).

7) DVGW: Work Sheets GW 9 (1989).

8) S. C. Dexter: Metals Handbook, 9th Ed., Vol. 13, "Corrosion", p. 119, ASM Internationa (1987).

9) G. Mclntire, J. Lippert \& J. Yudelson: Corrosion, 46, 91 (1990).

10) K. Kasahara \& F. Kajiyama: "Proc. Int. Congress on Microbially Influenced Corrosion and Biodeterioration", (Knoxville, USA, 7-12 Oct. 1990, NACE).

11) 後藤正志, 胡文志, 石井大道: 分析化学, 38, 419 (1989). 